\title{
Chemical composition and antibacterial activity of essential oils of Thymelaea hirsuta from Algeria
}

\author{
BOUNAB SOUHILA ${ }^{1}$, LOGRADA TAKIA $^{1}$, RAMDANI MESSAOUD $^{1, \vartheta}$, CHALARD PIERRE $^{2}$, \\ FIGUEREDO GILLES ${ }^{3}$ \\ ${ }^{1}$ Laboratory of Natural Resource Valorisation, SNV Faculty, Setif 1 University. 19000 Setif, Algeria. vemail: ramdanimessaoud@yahoo.com \\ ${ }^{2}$ Université Clermont Auvergne, CNRS, SIGMA Clermont, ICCF, F-63000 Clermont, Ferrand, France \\ ${ }^{3}$ LEXVA Analytique, 460 Rue Du Montant, 63110 Beaumont, France
}

Manuscript received: 10 August 2019. Revision accepted: 6 September 2019.

\begin{abstract}
Souhila B, Takia L, Messaoud R, Pierre C, Gilles F. 2019. Chemical composition and antibacterial activity of essential oils of Thymelaea hirsuta from Algeria. Biodiversitas 20: 2868-2876. The objectives of this study were to determine the chemical composition and to evaluate the antibacterial activity of Thymelaea hirsuta (L.) Endl., essential oils from seven sampling locations in M'sila region (Algeria). Extraction of essential oils was carried out by the hydro-distillation; the analysis of chemical composition of essential oil was carried out by GC-MS. Antimicrobial activity was performed by disc diffusion method at the essential oil concentration of non-diluted and diluted (1:2, 1:4 and 1:8 v:v of DMSO) against eight species of bacteria. The results showed that the average yields of essential oils were $0.3 \pm 0.12 \%$. A total of 45 components were identified, averaging $98.2 \pm 1.85 \%$ of the total oils. The main components were nonanal-n $(10.39 \pm 3.21 \%)$, hexadecanoic acid $(9.77 \pm 2.81 \%)$, nonanoic acid $(9.13 \pm 6.49 \%)$, triacontane $(7.2 \pm 3.34 \%)$, isopropyl tetradecanoate $(6.16 \pm 1.99 \%)$ and tridecane $(4.87 \pm 3.1 \%)$. Based on the UPGMA cluster analysis, there were two clades of T. hirsuta. T. hirusta has a chemical polymorphism with different chemotypes marked in nature. There were four chemotypes identified in the essential oil of $T$. hirsuta in the region of M'sila. The essential oil of $T$. hirsuta has antibacterial activity against eight tested bacteria on the concentration-dependentt manner.
\end{abstract}

Keywords: Algeria, antibacterial activity, chemotypes, essential oils, Thymelaea hirsuta

\section{INTRODUCTION}

The genus Thymelaea consists of 31 species with circum-Mediterranean distribution (Galicia-Herbada 2006). In Algeria, there are eight species of Thymelaea including T. hirsuta (L) Endl. (Quezel et Santa 1963). Previous studies showed that T. hirsuta has no toxic effects on humans (Bnouham et al. 2007; Azza et al. 2012). Various parts of $T$. hirsuta have been widely used in the paper industry (Schmidt et al. 1983).

In traditional medicine, $T$.hirsuta is used as antiseptic, anti-inflammatory and in the treatment of hypertension (Le Floc'h 1983; Azza et al. 2012; Bnouham et al. 2012; Azza and Oudghiri 2015). It is also used in hypoglycemic, antidiabetic drugs and as an antioxidant (Ziyyat et al. 1997; Djeridane et al. 2006; El Amrani et al. 2009; Akrout et al. 2011; Trigui et al. 2013; Yahyaoui et al. 2017, 2018a and b). T. hirsuta extracts are used as anti-melanogenesis (Kawano et al. 2007), anti-tumor (Akrout et al. 2011), anticholinesterase and anti-cytotoxic (Yahyaoui et al. 2018a). In Algeria, $T$. hirsuta is used as an antioxidant (Amari et al. 2014), and for the treatment of Leishmanicide and eczema (Boudjelal et al. 2013).

The aqueous extracts of T. hirsuta from eastern Algeria have an inhibitory activity to the growth of $S$. aureus and P. aeruginosa (Deramchia et al. 2017). Kadi et al. (2017) reported that $T$. hirsuta extracts from the Batna are effective against several bacterial species ( $P$. aeruginosa,
E. coli, and S. aureus). The essential oil of T. hirsuta has a potent antioxidant activity (Kadri et al. 2011), while essential oils of $T$. hirsuta from Tunisia have significant antibacterial activity against $S$. aureus, Enterobacter cloacae, Bacillus cereus, Enterococcus faecalis, Bacillus subtilis, Micrococcus luteus and Escherichia coli (Felhi et al. 2017).

Thymelaea hirsuta is rich in polyphenols, flavonoids, tannins, and alkaloids (Djeridane et al. 2006; Akrout et al. 2011; Trigui et al. 2013; Amari et al. 2014; Bouzouina et al. 2016; Yahyaoui et al. $2018 \mathrm{a}$ and b). The essential oil of T. hirsuta from Tunisia is very rich in heptane, germacrene-D, $\gamma$-eudesmol (Kadri et al. 2011; Benchobba et al. 2014). On the other hand, Yahyaoui et al. (2014) reported that the oils from Tunisian are composed of hexadecanoic acid, stylopsal, 4-8-dimethylhecosan, and 57-dodecadienal (Z, Z) (Table 1).

The aims of this study were to determine the chemical composition and to evaluate the antibacterial activity of essential oils of $T$. hirusta as a source of the natural antibiotic agent.

\section{MATERIALS AND METHODS}

\section{Plant materials}

Thymelaea hirsuta, synonym (Passerina hirsuta $\mathrm{L}$ and Passerina metnan Forsk), is belonging to the family 
Thymelaeaceae (Schmidt et al. 1983), a perennial shrubby plant can reach 2-3 meters in height. The small leaves are densely imbricated, coriaceous ovoid acute, glabrous below. The flowers are deciduous calyx, yellowish, polygamous, are at the tops of the branches (Figure 1). The fruit is a hairless berry (Quézel et Santa 1963).

Aerial parts of $T$. hirsuta were collected during the flowering stage in May 2017 from M'sila region (Figure 2). The geographical coordinates of sampling locations were noted using a GPS (Table 2).

\section{Essential oil extraction}

The air-dried materials were subjected to hydrodistillation for $3 \mathrm{~h}$ using a Clevenger apparatus type. Voucher specimens were deposited in the herbarium of the Department of Biology and Ecology, Setif University, Algeria. The oil obtained was collected and dried over anhydrous sodium sulfate and stored in screw-capped glass vials in a refrigerator at $4-5^{\circ} \mathrm{C}$ before analysis. The yield based on the dry weight of the samples was calculated.

\section{Essential oil analysis}

The essential oils were analyzed on a Hewlett-Packard gas chromatograph CPG/FID 7890, coupled to a gas chromatograph: CPG/MS 7890/5975C, equipped with a Column Apolar: DB5 MS (40m x 0.18mm; $0.18 \mu \mathrm{m})$, programming from $50^{\circ} \mathrm{C}$ for $5 \mathrm{~min}-5^{\circ} \mathrm{C} / \mathrm{min}$ until $300^{\circ} \mathrm{C}$. Helium was used as the carrier gas $(1.0 \mathrm{ml} / \mathrm{min})$; injection in split mode (1:30), injector and detector temperature is $280^{\circ} \mathrm{C}$ with split $1 / 100$. The mass spectrometer worked in EI mode at $70 \mathrm{eV}$; electron multiplier, $2500 \mathrm{~V}$; ion source temperature, $180^{\circ} \mathrm{C}$; MS data were acquired in the scan mode in the $\mathrm{m} / \mathrm{z}$ range 33450 . The identification of the components was based on comparison of their mass spectra with those of NIST mass spectral library (Masada 1979; NIST 2002) and those described by Adams as well as on comparison of their retention indices either with those of authentic compounds or with literature values (Adams 2007).

Table 1. Chemical composition of Thymelaea hirsuta essential oil of Tunisia

\begin{tabular}{lccc}
\hline Localities & $\begin{array}{c}\text { Gafsa and } \\
\text { Sidi Aich }\end{array}$ & $\begin{array}{c}\text { Tunisia } \\
\mathbf{1}\end{array}$ & $\begin{array}{c}\text { Tunisia } \\
\mathbf{2}\end{array}$ \\
\hline References & $\mathbf{A}$ & $\mathbf{B}$ & $\mathbf{C}$ \\
Hexadecanoic acid & 0 & 0 & 15.4 \\
Heptane & 28.34 & 34.2 & 0 \\
Citronellyl formate & 9.98 & 12.04 & 0 \\
Trans- $\beta$-caryophyllene & 3.25 & 3.92 & 0 \\
Germacrene-D & 12.98 & 15.66 & 0 \\
$\gamma$-cadinene & 2.55 & 3.08 & 0 \\
$\gamma$-Eudesmol & 11.81 & 14.25 & 0 \\
Tetradecamethyl-heptasiloxane & 11.83 & 0 & 0 \\
4, 8-dimethylhecosane & 0 & 0 & 12.9 \\
13-methylhexacosane & 0 & 0 & 5 \\
Stylopsal & 0 & 0 & 15.5 \\
5,7-dodecadienal (Z, Z)- & 0 & 0 & 12.2 \\
\hline Ne: A. Kadi
\end{tabular}

Note: A. Kadri et al. (2011); B. Benchobba et al. (2014); C. Yahyaoui et al. (2014)
Table 2. Geographical coordinates of sampling locations

\begin{tabular}{lllll}
\hline Localities & Lat $(\mathbf{N})$ & Lon $(\mathbf{E})$ & $\begin{array}{l}\text { Alt. } \\
(\mathbf{m})\end{array}$ \\
\hline 1 & Bouti sayeh & $35^{\circ} 63^{\prime} 18^{\prime \prime}$ & $3^{\circ} 72^{\prime} 55^{\prime \prime}$ & 647 \\
2 & Ain Lehdjel & $35^{\circ} 66^{\prime} 60^{\prime \prime}$ & $3^{\circ} 85^{\prime} 98^{\prime \prime}$ & 623 \\
3 & Mergueb & $35^{\circ} 60^{\prime} 14^{\prime \prime}$ & $3^{\circ} 93^{\prime} 95^{\prime \prime}$ & 630 \\
4 & Sidi Hadjress & $35^{\circ} 66^{\prime} 80^{\prime \prime}$ & $3^{\circ} 98^{\prime} 24^{\prime \prime}$ & 502 \\
5 & Ouanougha & $35^{\circ} 58^{\prime} 51^{\prime \prime}$ & $4^{\circ} 11^{\prime} 10^{\prime \prime}$ & 922 \\
6 & Ouled Mansour & $35^{\circ} 43^{\prime} 46^{\prime \prime}$ & $4^{\circ} 23^{\prime} 47^{\prime \prime}$ & 478 \\
7 & Ben Zouh & $35^{\circ} 51^{\prime} 75^{\prime \prime}$ & $4^{\circ} 08^{\prime} 65^{\prime \prime}$ & 713 \\
\hline
\end{tabular}

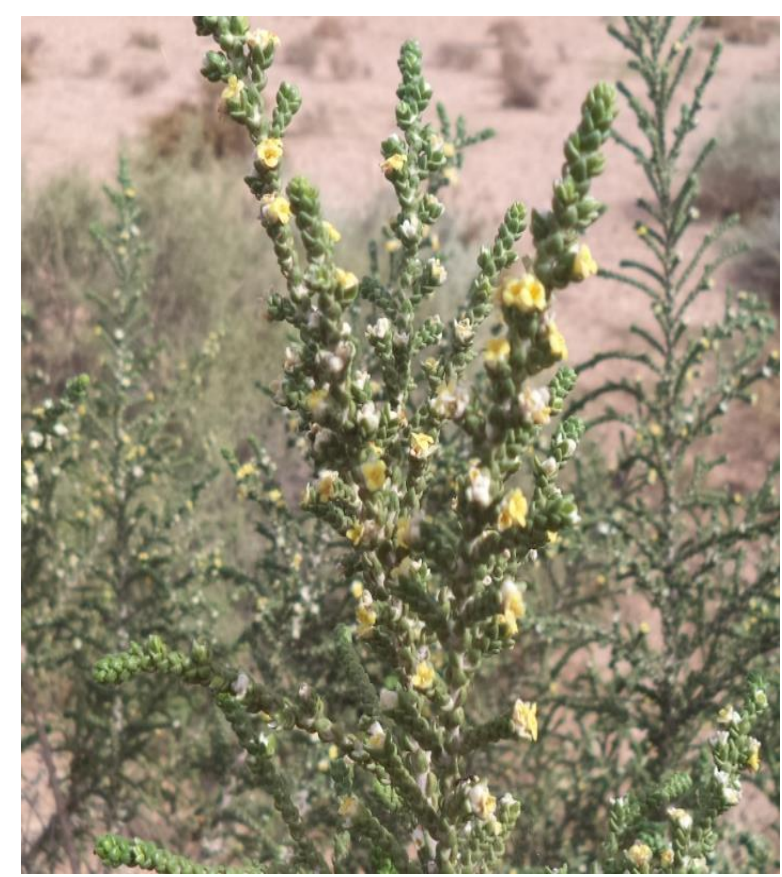

Figure 1. Thymelaea hirsuta from M'sila region, Algeria (Photograph: Bounab, 2017)

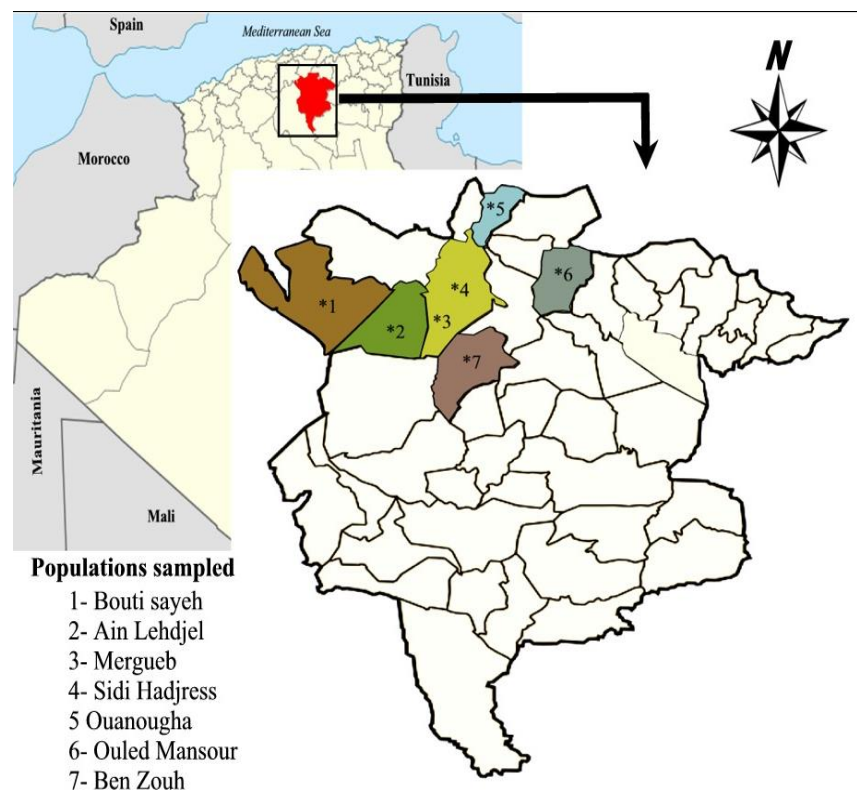

Figure 2. Locations of collected samples of Thymelaea hirsuta 


\section{Antibacterial activity assessment}

The in vitro evaluation of the antimicrobial activity was performed by the disc diffusion method against four Grampositive bacteria (Bacillus subtilis ATCC 6633, Bacillus cereus ATCC 11778, Staphylococcus aureus ATCC 25923, Enterococcus faecalis ATCC 51299) and four Gramnegative bacteria (Escherichia coli ATCC 25922, Salmonella enterica ATCC43972, Klebsiella pneumoniae ATCC 700603, and Pseudomonas aeruginosa ATCC 27853). The bacterial inoculums were prepared from overnight broth culture in physiological saline $(0.8 \% \mathrm{NaCl})$ to obtain an optical density range from $0.08-01$ at $625 \mathrm{~nm}$. Muller Hinton agar (MH agar) and MH agar supplemented with 5\% sheep blood for fastidious bacteria were poured in Petri dishes, solidified and surface dried before inoculation. Sterile discs $(6 \mathrm{~mm})$ were placed on inoculated agars with test bacteria, added with $10 \mu \mathrm{l}$ of stock solution of essential oil and diluted essential oil (1:2, 1:4 and 1:8 v:v of DMSO). DMSO was used as negative control. Bacterial growth inhibition was determined as the diameter of the inhibition zones around the discs. The Petri dishes were incubated at $37^{\circ} \mathrm{C}$ for 18 to $24 \mathrm{~h}$ aerobically. All the tests were performed in triplicate, and the means were calculated as final results. The sensitivity to essential oil was classified by diameter of inhibition halos as follows: not sensitive (-) for diameter less than $8 \mathrm{~mm}$; sensitive (+) for diameter 9-14 mm; very sensitive (++) for diameter 15-19 $\mathrm{mm}$ and extremely sensitive (+++) for diameter larger than $20 \mathrm{~mm}$ (Ponce et al. 2003).

\section{Statistical analysis}

Cluster analysis (UPGMA) was carried out on the original variables and on the Manhattan distance matrix to seek for hierarchical associations among the populations. The cluster analyses were carried out using STATISTICA 10 software. Statistical significance of antibacterial activity results were analyzed by the ANOVA three-way Completely Randomized (Populations, doses, and bacteria) by using the statistical software package (CoStat). All analyses are performed at the 5\% significance level (P $<0.05)$.

\section{RESULTS AND DISCUSSION}

\section{Chemical analysis}

The hydro-distillation of Thymelaea hirsuta essential oil gave a pale yellow viscous liquid. The average yield of essential oil of the samples was $0.3 \pm 0.12 \%$. The highest value $(0.4 \%)$ was obtained from the samples collected in Benzoh, Bouti Sayeh, and Ain Lehjel. The results of the analysis and identification of the essential oil components of $T$. hirsuta using GC-GC/MS was shown in Figure 3.

The chemical analysis of the essential oil of T. hirsuta by (GC / MS) showed a total of 45 identified compounds with the average of $(92.7 \pm 4.8 \%)$ of the total oil. The identified compounds and their abundance were presented in Table 3.
The chemical composition of $T$. hirsuta was dominated by nonanal-n $(10.39 \pm 3.21 \%)$, with the highest level was in the sample collected from Ouanougha $(16.7 \%)$. The second highest compound was hexadecanoic acid $(9.77 \pm$ $2.81 \%)$, followed by nonanoic acid $(9.13 \pm 6.49 \%)$, triacontane (7.2 $\pm 3.34 \%)$, isopropyl tetradecanoate $(6.16 \pm$ $1.99 \%)$ and tridecane $(4.87 \pm 3.1 \%)$.

The chemical classes of $T$. hirsuta essential oils showed significant variations between samples collected from different locations. Acids and aldehydes are dominant with an average of $23.25 \pm 9.67 \%$ and $20.25 \pm 5.12 \%$ respectively, followed by alkanes $(16.28 \pm 4.27 \%)$ and monoterpenes $(15.08 \pm 1.5 \%)$ (Figure 4).

Result of UPGMA Cluster Analysis (Figure 5) revealed two clades of T. hirsuta used in this study. The first clade includes samples from two locations of sampling (BoutiSayeh and Benzoh), that are characterized by the highest level of nonanoic acid (21.3 and 12.2\%).

The second clade groups consisted of samples collected from five sampling locations, which are characterized by hexadecanoic acid, in which samples from Sidi Hadjress deviates from the group by the presence of a high level of triacontane $(7.2 \%)$. Based on this statistical analysis, four chemotypes were identified that characterize $T$. hirsuta in Algeria (Table 4).

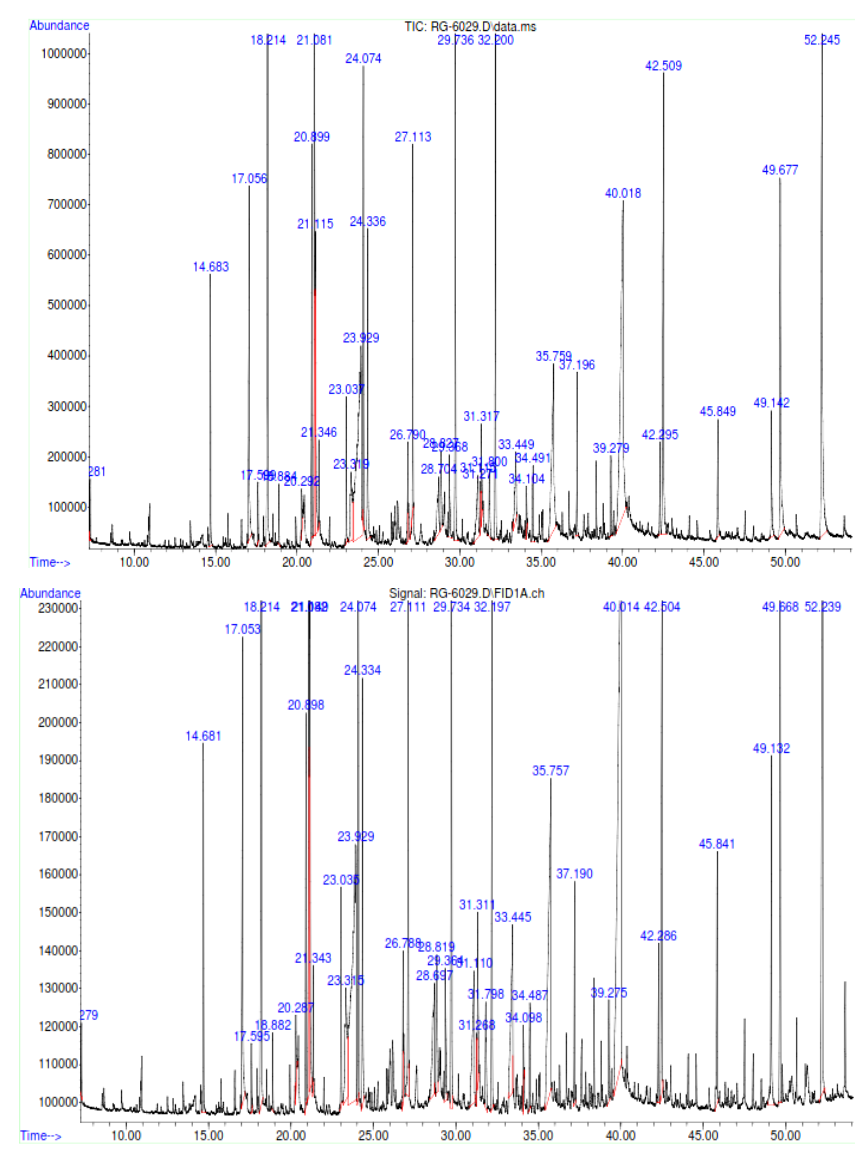

Figure 3. GC/Masse and GC/FID profiles of Thymelaea hirsuta 
Table 3. Chemical composition of Thymelaea hirsuta essential oils from 7 sampling locations in M'sila region, Algeria

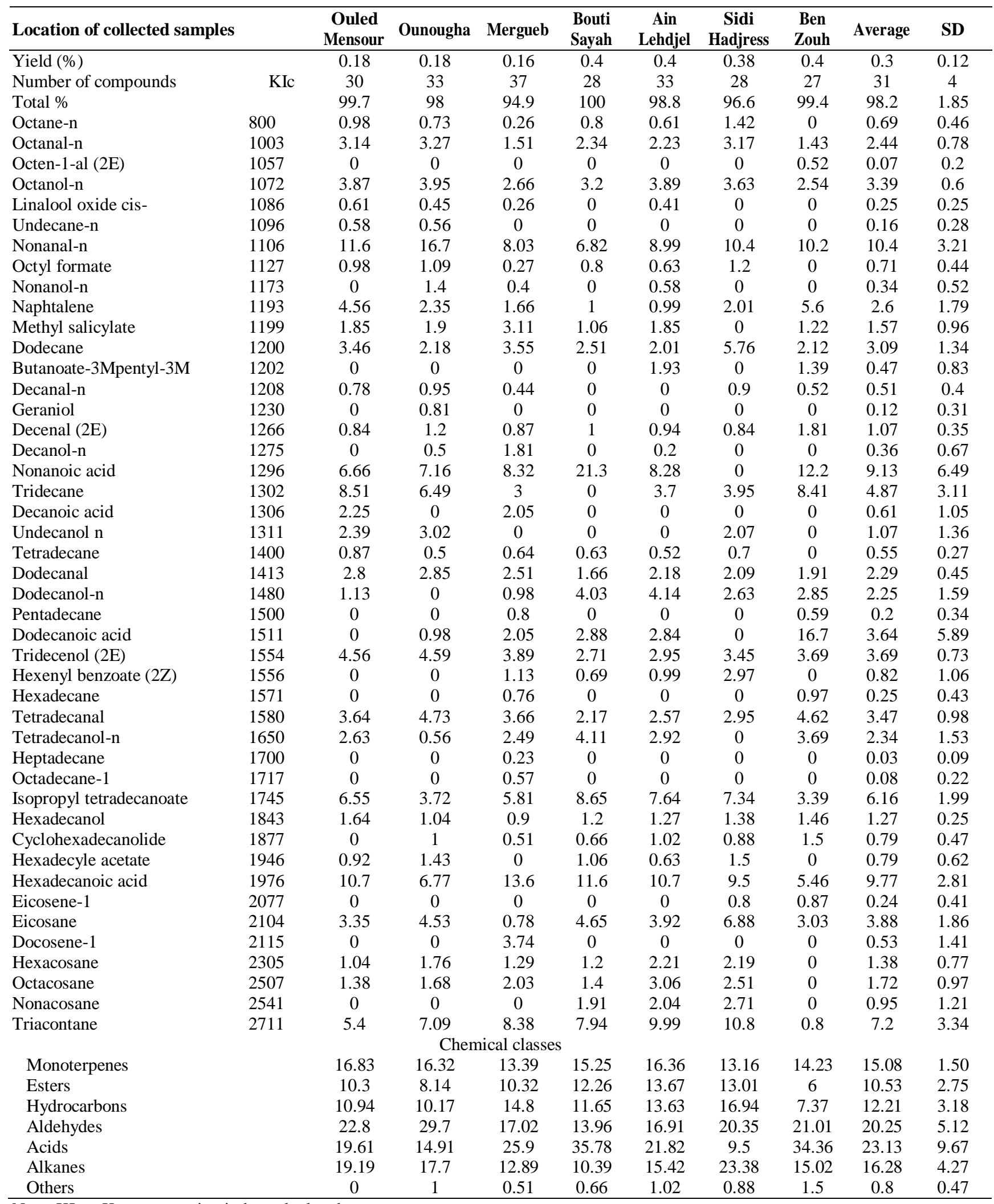

Note: KIc $=$ Kovats retention index calculated 
Table 4. Chemotypes of Thymelaea hirsuta in M'sila region, Algeria

\begin{tabular}{|c|c|c|c|c|}
\hline \multicolumn{4}{|c|}{ Chemotypes } & \multirow{2}{*}{$\begin{array}{l}\begin{array}{l}\text { Locations } \\
\text { of sampling }\end{array} \\
\text { Benzouh }\end{array}$} \\
\hline 1 & $\begin{array}{l}\text { Nonanoic } \\
\text { acide }\end{array}$ & $\begin{array}{l}\text { Decanoic } \\
\text { acid }\end{array}$ & Nonanal-n & \\
\hline 2 & & $\begin{array}{l}\text { Hexadecanoic } \\
\text { acid }\end{array}$ & $\begin{array}{l}\text { Isopropyl } \\
\text { tetra } \\
\text { decanoiate }\end{array}$ & Bouti sayeh \\
\hline \multirow[t]{2}{*}{3} & $\begin{array}{l}\text { Hexadecanoic } \\
\text { acid }\end{array}$ & $\begin{array}{l}\text { Nonanoic } \\
\text { acid }\end{array}$ & Nonanol- $\mathrm{n}$ & $\begin{array}{l}\text { Ouled } \\
\text { Mansour, } \\
\text { Ouanougha }\end{array}$ \\
\hline & & & Triacantane & $\begin{array}{l}\text { Mergueb, } \\
\text { Ain } \\
\text { Lehdjel }\end{array}$ \\
\hline 4 & & Triacantane & & $\begin{array}{l}\text { Sidi } \\
\text { Hadjress }\end{array}$ \\
\hline
\end{tabular}

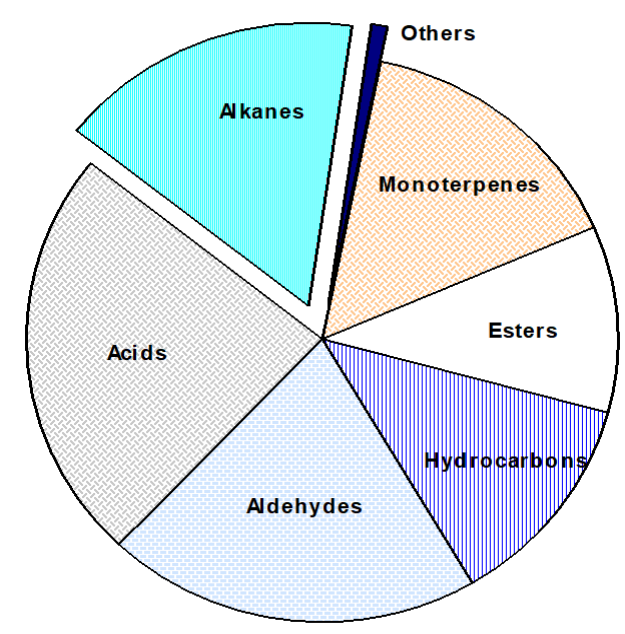

Figure 4. Chemical classes of Thymelaea hirsuta oils

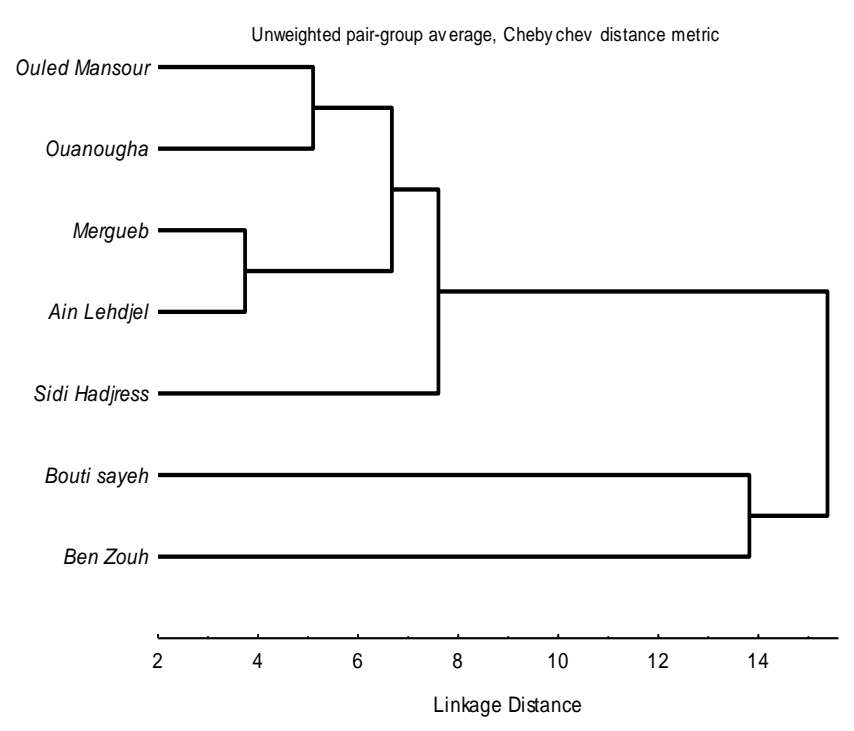

Figure 5. UPGMA cluster analysis of Thymelaea hirsuta in M'sila, Algeria

\section{Antibacterial activity}

The in vitro evaluation of antimicrobial activity was performed by the diffusion method against eight species of bacteria. All bacteria species tested showed high sensitivity to the essential oil of T. hirsuta (Table 5).

The ANOVA statistical analysis (three Way Completely Randomized) showed that sampling locations, doses, and bacterial species, and their interactions are very highly significant $(\mathrm{P}<0.001)$ (Table 6).

The antibiotic susceptibility test showed that the activity of antibiotic standard (gentamicin) varied according to the species of bacteria. The antibiotic (gentamicin) tested showed a higher growth inhibition than the oils against the bacteria used (group a) (Table 7). Of the four tested concentrations, pure oil exhibited the most potent effect compared to diluted oils (group b).

The most effective oils against the tested bacteria were those of $T$. hirsuta collected from Sidi Hajress, Ouanougha and Bouti Sayeh, forming the group (a). On the other hand, the least antibacterial activity is the oil from T. hirsuta collected from Ouled Mansour (Table 8).

The antibacterial activity of T. hirsuta essential oil was qualitatively assessed by the diameter of inhibitory zone. The results indicated that the tested oils exhibited a significant antibacterial activity against all the tested bacteria, but on a concentration dependent-manner (Table 9 ). The highest average of inhibition zone diameters was recorded against Salmonella enterica $(18.64 \mathrm{~mm})$, while the lowest average of inhibition zone diameter was recorded against Enterococcus foecalis (12.07 mm).

\section{Discussion}

Hydro-distillation of the aerial parts of $T$. hirsuta gives an average yield of essential oils of $0.3 \pm 0.12 \%$, and this result was similar to the study by Kadri et al. (2011). Variations in essential oil yields from different sampling locations may be due to several factors, especially interaction with the environment (the type of climate, soil), harvest time and extraction methods (Viljoen et al. 2006; Sefidkon et al. 2007).

The chemical composition of T. hirsuta essential oils was dominated by nonanal-n, hexadecanoic acid, nonanoic acid, triacontane, and isopropyl tetradecanoate. The composition of the essential oils in this study was different from that of collected in Tunisia, whose major compounds were heptane, germacrene-D, eudesmol and citronellyl formate (Kadri et al. 2011; Benchobba et al. 2014). Other studies by Yahyaoui et al. (2014) showed that the essential oil of $T$. hirsuta grown in Tunisia contained stylopsal, hexadecanoic acid, and 5,7-dodecadienal- (Z, Z) (2014).

UPGMA cluster analysis allowed us to compare chemical compounds of $T$. hirsuta from this study with those of the literature (Figure 6). Two clades are different and well separated. The first clade includes samples collected from Gafsa, Sidi Aich and Tunisia (1), which are characterized by the presence of heptane in high proportions, germacrene-D and $\gamma$-eudesmol (Kadri et al. 2011; Benchobba et al. 2014). These populations may represent a chemotype with heptane and germacrene-D compounds, as in sample collected from Tunisia. 
Table 5. Inhibition diameter ( $\mathrm{mm}$ ) of Thymelaea hirsuta essential oils against eight bacteria species

\begin{tabular}{|c|c|c|c|c|c|c|c|c|}
\hline Species of bacteria & Dilutions & Bouti Sayeh & Mergueb & Ain Lehjel & Ouanougha & $\begin{array}{c}\text { Ouled } \\
\text { Mansour }\end{array}$ & Benzoh & $\begin{array}{c}\text { Sidi } \\
\text { Hajress }\end{array}$ \\
\hline Pseudomonas & 1 & $14 \pm 1.15$ & $15 \pm 2$ & $12 \pm 2$ & $15 \pm 2$ & $14 \pm 2$ & $12 \pm 1$ & $15 \pm 2$ \\
\hline aeruginosa ATCC & $1 / 2$ & $12 \pm 1$ & $12 \pm 1.52$ & $9 \pm 0.6$ & $12 \pm 1$ & $11 \pm 1.15$ & $9 \pm 1.52$ & $12 \pm 1$ \\
\hline \multirow[t]{3}{*}{27853} & $1 / 4$ & $11 \pm 1.15$ & $10 \pm 0.57$ & $9 \pm 5.3$ & $9 \pm 1.5$ & $9 \pm 0.57$ & $9 \pm 5.19$ & $11 \pm 1.5$ \\
\hline & $1 / 8$ & $9.33 \pm 0.6$ & $9 \pm 0$ & 0 & $8 \pm 0.6$ & $9 \pm 0$ & 0 & $9.33 \pm 0.6$ \\
\hline & \multicolumn{8}{|c|}{ Gentamicin $=28 \pm 1$} \\
\hline Klebsiella & 1 & $17 \pm 1.52$ & $18 \pm 1.15$ & $14 \pm 2.9$ & $16 \pm 1.5$ & $14 \pm 3.6$ & $19 \pm 1.52$ & $15 \pm 1.2$ \\
\hline pneumoniea ATCC & $1 / 2$ & $14 \pm 0.57$ & $12 \pm 1$ & $10 \pm 0.6$ & $12 \pm 0$ & $10 \pm 0$ & $13 \pm 1.15$ & $11 \pm 0.6$ \\
\hline \multirow[t]{3}{*}{700603} & $1 / 4$ & $12 \pm 0.54$ & $9 \pm 1.15$ & $9 \pm 0.6$ & $10 \pm 0$ & $9 \pm 0$ & $12 \pm 1$ & $8 \pm 0.6$ \\
\hline & $1 / 8$ & $10 \pm 1.52$ & $9 \pm 1.73$ & 0 & $9 \pm 0$ & 0 & $10 \pm 0.57$ & 0 \\
\hline & \multicolumn{8}{|c|}{ Gentamicin $=31.33 \pm 1.52$} \\
\hline Escherichia coli & 1 & $20 \pm 2.08$ & $10 \pm 1.15$ & $13 \pm 1.2$ & $14 \pm 1$ & $17 \pm 2$ & $16 \pm 2.64$ & $31 \pm 3.6$ \\
\hline \multirow[t]{4}{*}{ ATCC 25922} & $1 / 2$ & $13 \pm 1.73$ & $9 \pm 0.57$ & $9 \pm 0.6$ & $11 \pm 0$ & $11 \pm 1.15$ & $10 \pm 0.57$ & $22 \pm 3.8$ \\
\hline & $1 / 4$ & $10 \pm 0.57$ & $8 \pm 0.57$ & $9 \pm 5.2$ & $10 \pm 1$ & $10 \pm 1$ & $9 \pm 0.57$ & $17 \pm 3.1$ \\
\hline & $1 / 8$ & $9 \pm 1.15$ & 0 & 0 & 0 & 0 & 0 & $13 \pm 1.5$ \\
\hline & \multicolumn{8}{|c|}{ Gentamicin $=30.66 \pm 1.15$} \\
\hline Salmonella enterica & 1 & $24 \pm 3.05$ & $24 \pm 3.78$ & $21 \pm 2.5$ & $24 \pm 4$ & $11 \pm 1.52$ & $20 \pm 1.15$ & $27 \pm 3.5$ \\
\hline \multirow{4}{*}{ ATCC43972 } & $1 / 2$ & $20 \pm 2.08$ & $11 \pm 1.15$ & $15 \pm 3.2$ & $22 \pm 3$ & $10 \pm 0$ & $15 \pm 3$ & $10 \pm 0.6$ \\
\hline & $1 / 4$ & $14 \pm 3.21$ & $10 \pm 0.57$ & $12 \pm 1.5$ & $15 \pm 5.7$ & $9 \pm 1.15$ & $12 \pm 2.08$ & $10 \pm 0$ \\
\hline & $1 / 8$ & $11 \pm 1.52$ & $8.33 \pm 0.6$ & $10 \pm 1.2$ & $11 \pm 1.7$ & $8 \pm 0$ & $10 \pm 3.88$ & 0 \\
\hline & \multicolumn{8}{|c|}{ Gentamicin $=35.33 \pm 0.57$} \\
\hline Bacillus cereus & 1 & $21 \pm 3.51$ & $11 \pm 1.52$ & $22 \pm 3.1$ & $17 \pm 1.5$ & $21 \pm 2.51$ & $15 \pm 1.52$ & $24 \pm 4.01$ \\
\hline \multirow[t]{4}{*}{ ATCC 11778} & $1 / 2$ & $9 \pm 0.57$ & $8 \pm 0.57$ & $15 \pm 1.5$ & $13 \pm 0.6$ & $14 \pm 3.60$ & $11 \pm 1$ & $14 \pm 4.7$ \\
\hline & $1 / 4$ & 0 & $8.33 \pm 0.6$ & $11 \pm 0.6$ & $11 \pm 1$ & $11 \pm 2$ & $9 \pm 1$ & $12 \pm 3.2$ \\
\hline & $1 / 8$ & 0 & 0 & $9 \pm 0.6$ & $9 \pm 0.6$ & $9.33 \pm 0.6$ & $9.33 \pm 0.6$ & $10 \pm 1.5$ \\
\hline & \multicolumn{8}{|c|}{ Gentamicin $=33 \pm 1$} \\
\hline Staphylococcus & 1 & $20 \pm 1.52$ & $16 \pm 1.52$ & $14 \pm 1.7$ & $17 \pm 1.2$ & $12 \pm 1.52$ & $12 \pm 1$ & $21 \pm 2.5$ \\
\hline aureus ATCC & $1 / 2$ & $14 \pm 1$ & $13 \pm 0.57$ & $12 \pm 1$ & $13 \pm 0.6$ & $11 \pm 1$ & $10 \pm 0.57$ & $15 \pm 1.5$ \\
\hline \multirow[t]{3}{*}{25923} & $1 / 4$ & $11 \pm 1.52$ & $11 \pm 1.52$ & $10 \pm 1$ & $10 \pm 0.6$ & $9 \pm 1.15$ & $9 \pm 0.57$ & $12 \pm 1.2$ \\
\hline & $1 / 8$ & $9 \pm 1$ & $9 \pm 0$ & $9 \pm 0$ & $9 \pm 0.6$ & 0 & 0 & $10 \pm 1$ \\
\hline & \multicolumn{8}{|c|}{ Gentamicin $=30.33 \pm 0.57$} \\
\hline Bacillus subtilis & 1 & $16 \pm 1.52$ & $24 \pm 2$ & $25 \pm 3.1$ & $21 \pm 2.1$ & $13 \pm 1.52$ & $17 \pm 2$ & $14 \pm 2.1$ \\
\hline \multirow[t]{4}{*}{ ATCC 6633} & $1 / 2$ & $13 \pm 1.73$ & $19 \pm 3.05$ & $16 \pm 1.5$ & $17 \pm 0.6$ & $11 \pm 1.15$ & $13 \pm 0.6$ & $11 \pm 2.5$ \\
\hline & $1 / 4$ & $11 \pm 1.52$ & $14 \pm 1.52$ & $14 \pm 1.7$ & $13 \pm 0.6$ & $9 \pm 1.52$ & $11 \pm 0.6$ & $10 \pm 2.1$ \\
\hline & $1 / 8$ & $10 \pm 1.73$ & $11 \pm 1.52$ & $12 \pm 1$ & $10 \pm 1.2$ & $8.33 \pm 0.6$ & $9 \pm 1$ & $10 \pm 1.7$ \\
\hline & \multicolumn{8}{|c|}{ Gentamicin $=26 \pm 1$} \\
\hline Enterococcus & 1 & $16 \pm 1.15$ & $17 \pm 2$ & $14 \pm 0.6$ & $18 \pm 1.7$ & $13 \pm 1.15$ & $16 \pm 1.15$ & $14 \pm 1$ \\
\hline faecalis ATCC & $1 / 2$ & $13 \pm 0.57$ & $14 \pm 1$ & $12 \pm 1.2$ & $14 \pm 1.2$ & $11 \pm 1$ & $14 \pm 1$ & $11 \pm 1.52$ \\
\hline \multirow{3}{*}{51299} & $1 / 4$ & $12 \pm 1$ & $11 \pm 1.15$ & $10 \pm 0.6$ & $11 \pm 1.2$ & $10 \pm 1$ & $11 \pm 1.52$ & $10 \pm 0.6$ \\
\hline & $1 / 8$ & $9 \pm 1$ & $9.33 \pm 0.6$ & $9 \pm 0$ & $9 \pm 0.6$ & $8.33 \pm 0.6$ & $9 \pm 1.15$ & $9 \pm 0$ \\
\hline & \multicolumn{8}{|c|}{ Gentamicin $=12.9 \pm 0.1$} \\
\hline
\end{tabular}

Table 6. Main effects and interactions of essential oils of Thymelaea hirsuta

\begin{tabular}{lccc}
\hline Sources & df & F & P \\
\hline Main effects & & & \\
$\quad$ Sampling locations & 6 & 35.21 & $.0000 * * *$ \\
$\quad$ Doses & 4 & 4496.93 & $.0000 * * *$ \\
$\quad$ Species of bacteria & 7 & 148.79 & $.0000 * * *$ \\
Interactions & & & \\
$\quad$ Sampling locations * Doses & 24 & 5.66 & $.0000 * * *$ \\
$\quad$ Sampling locations * Species of & 42 & 30.88 & $.0000 * * *$ \\
$\quad$ bacteria & & & \\
$\quad \begin{array}{l}\text { Doses * Species of bacteria } \\
\quad \text { Sampling locations * Doses * }\end{array}$ & 168 & 84.45 & $.0000 * * *$ \\
$\quad$ Species of bacteria & & & $.0000 * * *$ \\
\hline Note: *** Very highly significant $(\mathrm{P}<0.001)$ & & \\
\hline
\end{tabular}

Table 7. Effect of oil dilutions on the inhibitory zone of tested bacteria

\begin{tabular}{|c|c|c|c|c|c|}
\hline Rank & Doses & $\begin{array}{l}\text { Mean } \\
\text { inhibition } \\
\text { zones }\end{array}$ & $\mathbf{n}$ & $\begin{array}{l}\text { Significant } \\
\text { groups }\end{array}$ & \\
\hline 1 & Gentamicin & 28.45 & 168 & $\mathrm{a}$ & \\
\hline 2 & 1 & 17.54 & 168 & $\mathrm{~b}$ & \\
\hline 3 & 0.5 & 12.96 & 168 & c & \\
\hline 4 & 0.25 & 10.75 & 168 & & $\mathrm{~d}$ \\
\hline 5 & 0.125 & 6.92 & 168 & & e \\
\hline
\end{tabular}


Table 8. The effectiveness of $T$. hirsuta essential oils from several sampling locations against eight bacteria species

\begin{tabular}{lllllllll}
\hline Rank & $\begin{array}{l}\text { Sampling } \\
\text { location }\end{array}$ & $\begin{array}{c}\text { Mean } \\
\text { inhibition } \\
\text { zones }\end{array}$ & n & \multicolumn{2}{l}{ Significant groups } \\
\hline 1 & Sidi Hajress & 16.31 & 120 & a & & & \\
2 & Ouanougha & 16.13 & 120 & a & & & \\
3 & Bouti Sayeh & 15.99 & 120 & a & & & & \\
4 & Mergueb & 15.12 & 120 & & b & & & \\
5 & Ain Lehjel & 15.07 & 120 & & & bc & & \\
6 & Benzoh & 14.71 & 120 & & & & c & \\
7 & Ouled & 13.92 & 120 & & & & & d \\
& Mansour & & & & & & & \\
\hline
\end{tabular}

Note: LSD $0.05=0.40580171325$

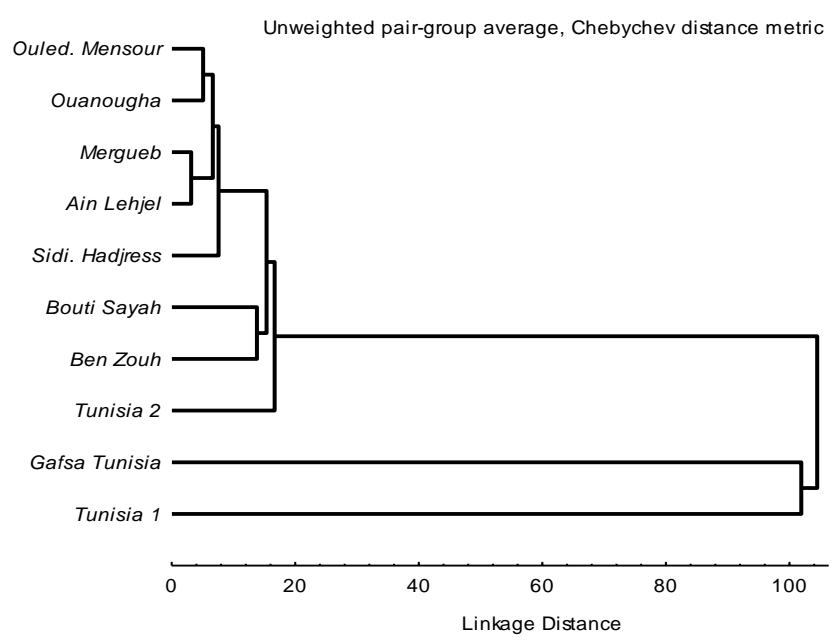

Figure 6. UPGMA of essential oils of Thymelaea hirsuta populations

The second clade was clustered between $T$. hirsuta in this study with that of collected in Tunisia (2). The Tunisian (2) was characterized by the presence of hexadecanoic acid and stylopsal (Yahyaoui et al. 2014). This composition may represent a second Tunisian chemotype.

The essential oil of $T$. hirsuta from the M'sila region has antibacterial activity against the tested bacterial species. These bacterial species are highly sensitive, except Enterococcus foecalis which shows low sensitivity to the essential oil of $T$. hirsuta with inhibition diameters of 10 to $18 \mathrm{~mm}$ for all tested dilutions. This sensitivity gives it the status of sensitive bacteria (+), but statistically, it is the least sensitive, among the bacteria tested, to the oils of the seven populations studied. It is classified in the last group (e) with an average zone of inhibition of $12.07 \mathrm{~mm}$.

Compared to the reference antibiotic, similar degrees of inhibitory effects of pure essential oils were observed on Gram-negative bacteria; with inhibitory zones of 10-31 $\mathrm{mm}$. All the dilutions have shown more potent effect against Gram-positive bacteria than Gram-negative ones. All dilutions showed, overall, a more potent effect against Gram-positive bacteria than Gram-negative bacteria.
Table 9. Sensitivity groups of tested bacteria with essential oils of Thymelaea hirsuta

\begin{tabular}{|c|c|c|c|c|c|}
\hline Rank & Species of bacteria & $\begin{array}{l}\text { Mean } \\
\text { inhibi } \\
\text { tion } \\
\text { zones }\end{array}$ & $\mathbf{n}$ & $\begin{array}{l}\text { Significant } \\
\text { groups }\end{array}$ & $\mathbf{S}^{*}$ \\
\hline 1 & Salmonella enterica & 18.64 & 105 & $\mathrm{a}$ & ++ \\
\hline 2 & Bacillus subtilis & 16.33 & 105 & $\mathrm{~b}$ & ++ \\
\hline 3 & Bacillus cereus & 16.03 & 105 & $\mathrm{~b}$ & ++ \\
\hline 4 & Staphylococcus aureus & 15.36 & 105 & $\mathrm{c}$ & ++ \\
\hline 5 & Escherichia coli & 15.20 & 105 & $\mathrm{c}$ & ++ \\
\hline 6 & Klebsiella pneumoniae & 15.13 & 105 & $\mathrm{c}$ & ++ \\
\hline 7 & Pseudomonas aeruginosa & 13.83 & 105 & $\mathrm{~d}$ & ++ \\
\hline 8 & Enterococcus foecalis & 12.07 & 105 & & + \\
\hline
\end{tabular}

It is noted that the concentration of essential oils directly influences the inhibitory activity, when the concentration of the oil increases, the diameters of inhibitions are important, similar remarks were made by Emiroglu et al. (2010).In addition, the presence of oxygenated terpenes and especially oxygenated monoterpenes in essential oils may be responsible for the pronounced activity of oils (Akrout et al. 2010; Taran et al. 2010; Ben Marzoug et al. 2011; Bencheqroun et al. 2012). Antibacterial activity appears to result from a combination of the diversity of molecules present in Essential oils and several modes of action (Calsamiglia et al. 2007, Goetz and Ghedira 2012). On the other hand, the method used to study the antibacterial effect of essential oil can be considered as a factor influencing the zones of inhibition (Fazeli et al. 2007).

Kadi et al. (2017) and Deramchia et al. (2017) reported that essential oils of $T$. hirsuta had antibacterial activity. Trigui et al. 2013; and Felhi et al. (2017) also reported that T. hirsuta extracts from Tunisia were also able to inhibit the growth of bacteria.

In conclusion, this study showed that the yield of $T$. hirsuta essential oils by hydrodistillation was very low $(0.3$ $\pm 0.12 \%$ ). There were two clades of $T$. hirsuta in Algeria. The $1^{\text {st }}$ clades have a high content of nonanoic acid, and the $2^{\text {nd }}$ clade has a high content of hexadecanoic acid. Four chemotypes have been identified from the essential oil of $T$. hirsuta from Algeria. The essential oil of T. hirsuta was able to inhibit the growth of eight species tested bacteria. The preliminary results obtained are promising in expanding the therapeutic arsenal of plants with antibacterial properties. However, the in vitro methods used to confirm the antibacterial activity of essential oils are insufficient and require further, more advanced, additional testing. More detailed future studies should be performed to identify the antimicrobial activity of essential oils of $T$. hirsute.

\section{ACKNOWLEDGEMENTS}

The work was supported by Algerian MESRS and LEXVA Analytique, France. 


\section{REFERENCES}

Adams RP. 2007. Identification of essential oils components by Gas Chromatography-Mass spectroscopy. Allured Publishing Corporation Carol Stream, Illinois, USA.

Akrout A, Alarcon Gonzalez L, El Jani H, Campra Madrid P. 2011. Antioxidant and antitumor activities of Artemisia campestris and Thymelaea hirsuta from southern Tunisia. Food Chem Toxicol 49 (2): 342-347. DOI: 10.1016/j.fct.2010.11.003

Akrout A, El Jani H, Amouri S and Neffati M. 2010. Screening of antiradical and antibacterial activities of essential oils of Artemisia campestris L., Artemisia herba alba Asso and Thymus capitatus Hoff. et Link. Growing wild in the Southern of Tunisia. Recent Research in Science and Technology 2 (1): 29-39.

Amari O-N, Bouzouina M, Berkani A, Lotmani B. 2014. Phytochemical screening and antioxidant capacity of the aerial parts of Thymelaea hirsuta L. Asian Pac J Trop Dis 4 (2): 104-109. DOI: 10.1016/S22221808 (14)60324-8

Azza Z and Oudghiri M. 2015. In vivo anti-inflammatory and antiarthritic activities of aqueous extracts from Thymelaea hirsuta. Pharmacogn Res 7 (2): 213-216. DOI: 10.4103/0974-8490.150510

Azza Z, Marnissi F, Naya A, Benjelloun N, Zamyati S, Amrani M, Oudghiri M. 2012. Toxicological evaluation of Thymelaea hirsuta and protective effect against $\mathrm{CCl} 4$-induced hepatic injury in rats. Intl J Biol Chem Sci 6 (1): 379-393. DOI: 10.4314/ijbcs.v6i1.33

Ben Marzoug HN, Romdhane M, Lebrihi A, Mathieu F, Couderc F Abderraba M, Khouja ML and Bouajila J. 2011. Eucalyptus oleosa essential oils: Chemical composition, antimicrobial, and antioxidan activities of the oils from different plant parts (stems, leaves, flowers, and fruits). Molecules 16 (2): 1695-1709. DOI: 10.3390/molecules16021695.

Bencheqroun HK, Ghanmi M, Satrani B, Aafi A et Chaouch A. 2012 Activité antimicrobienne des huiles essentielles d'Artemisia mesatlantica, plante endémique du Maroc. Bulletin de la Société Royale des Sciences de Liège 81: 4-21.

BenChobba I, Felhi S, Chaaibia M, Ben Mansour R, Békir A, Drira N, Gharsallah N, Kadri A. 2014. Phytochemical composition and biological assays of the aerial parts of Thymelaea hirsuta essential oil from Tunisia. The third international symposium on Biology of rare and endemic plant species. Antalya. Turkey (19-23 April): 1-73. http://www.iseo2014.org/location.html

Bnouham M, Benalla W, Bellahcen S, Hakkou Z, Ziyyat A, Mekhfi H, Aziz M, Legssyer A. 2012. Antidiabetic and antihypertensive effect of a polyphenol rich fraction of Thymelaea hirsute L. in a model of neonatal streptozotocin diabetic and NG-nitro-l-arginine methyl esterhypertensive rats. J Diabetes 4 (3): 307-313. DOI: 10.1111/j.17530407.2012.00202.x

Bnouham M, Merhfour FZ, Legssyer A, Mekhfi H, Maâllem S, Ziyyat A 2007. Antihyperglycemic activity of Arbutus unedo, Ammoides pusilla and Thymelaea hirsuta. Pharmazie 62 (8): 630-632.

Boudjelal A, Henchiri C, Sari M, Sarri D, Hendel N, Benkhaled A, Ruberto G. 2013. Herbalists and wild medicinal plants in M'Sila (North Algeria): An ethnopharmacology survey. J Ethnopharmaco 148 (2): 395-402. DOI: 10.1016/j.jep.2013.03.082

Bouzouina M, Amari N-O, Berkani A, Lotmani B, Hanafi M and Lazizi A. 2016. Total phenolics contents, flavonoids contents, and fatty acids compositions in Thymelaea hirsuta L. aerial parts, grown in Western Algeria. Adv Environ Biol 10 (1): 16-22.

Calsamiglia S, Busquet M, Cardozo PW, Castillejos L et Ferret A. 2007. Invited Review: Essential oils as modifiers of rumen microbia fermentation. Journal of Dairy Science 90: 2580-259.

Deramchia N, Belhakem M. 2017. Antimicrobial activity of phenolic extracts and essential oil from Thymelaea hirsuta. South Asian J Exp Biol 7 (1): 35-41. http://sajeb.org/index.php/sajeb/article/view/20374

Djeridane A, Yousfi M, Nadjemi B, Boutassouna D, Stocker P, Vidal N. 2006. Antioxidant activity of some Algerian medicinal plants extracts containing phenolic compound. Food Chem 97 (4): 654-660. DOI 10.1016/j.foodchem.2005.04.028

El Amrani F, Rhallab A, Alaoui T, El Badaoui K, Chakir S. 2009. Hypoglycemic effect of Thymelaea hirsuta in normal and streptozotocin-induced diabetic rats. J. Med Plants Res 3 (9): 625 629

Emiroğlu ZK, Yemis GP, Coskum BK, Candogan K. 2010. Antimicrobial activity of soy edible films incorporated with thyme and oregano essential oil on fresh ground beef patties. Meat Sci 86 (2): 283-286. DOI: $10.1016 /$ j.meatsci.2010.04.016

Fazeli MR, Amin G, Ahmadian-Attari MM, Ashtiani H, Jamalifar $\mathrm{H}$ and Samadi N. 2007. Antimicrobial activities of Iranian sumac and avishane shirazi (Zataria multiflora) against some food-borne bacteria. Food Control 18 (6): 646-649. DOI: 10.1016/j.foodcont.2006.03.002.

Felhi S, Chaaibia M, Bakari S, Ben Mansour R, Békir A, Gharsallah N and Kadri A. 2017. Anti-microbial screening and cytotoxic activity of aerial part of Thymelaea hirsuta L essential oil growing in south-west Tunisia. Pak J Pharm Sci 30 (1): 87-91.

Galicia-Herbada D. 2006. Origin and diversification of Thymelaea (Thymelaeaceae): inferences from a phylogenetic study based on its (rDNA) sequences. Plant Syst Evol 257 (3-4): 159-187. DOI: 10.1007/s00606-005-0371-z

Goetz P, Ghedira K. 2012. Phytothérapie anti-infectieuse. SpringerVerlag, France, Paris.

Kadi K, Hamli S, Zeraib A, Yahia A. 2017. Effet antibactérien des extraits de Thymelaea hirsuta L. Revue des Régions Arides n43- Numéro spécial - Actes du 5ème Meeting International sur l'Aridoculture et les Cultures Oasiennes : Biotechnologie végétale en zones arides et oasiennes Zarzis (Tunisie) 43 (3): 409-419.

Kadri A, Zarai Z, Ben Chobba I, Gharsallah N, Damak M, Békir A. 2011. Chemical composition and in vitro antioxidant activities of Thymelaea hirsuta L essential oil from Tunisia. African J Biotechnol 10 (15): 2930-2935. DOI: 10.5897/AJB11.028

Kawano M, Matsuyama K, Miyamae Y, Shinmoto H, Kchouk M E, Morio T, Shigemori H, Isoda H. 2007. Antimelanogenesis effect of Tunisian herb Thymelaea hirsuta extract on B16 murine melanoma cells. Exp Dermatol 16 (12): 977-984. DOI: 10.1111/j.1600-0625.2007.00618.x

Le Floc'H E. 1983. Contribution à une étude ethnobotanique de la flore tunisienne. Publ. sci. tunisiennes. Programme flore et végétation tunisienne, Vol. 1, 402p. http://www.ethnopharmacologia.org/ bibliotheque-ethnopharmacologie/

Masada Y. 1979. Analysis of essential oils by Gas Chromatography and Mass Spectrometry. John Wiley \& Sons, Inc., New York.

NIST, 2002. Mass Spectral Search Program for the NIST/EPA/NIH. Mass Spectral Library, Vers. 2.0. Fiveash data, USA

Ponce A G, Fritz R, Del Valle C-E and Rora S I. 2003. Antimicrobial activity of essential oils on the native microflora of organic Swiss chard. Lebensmittel-Wissenschaft und Technologie 36 (7): 679-684. DOI: 10.1016/S0023-6438 (03)00088-4

Quezel P, Santa S. 1962-1963. Nouvelle Flore de l'Algérie et des régions désertiques méridionales, ed. CNRS, Paris, 2 Tomes, 1170. http://bibliotheques.mnhn.fr/medias/doc/exploitation/horizon/493163

Schmidt J and Stavisky N. 1983. Uses of Thymelaea hirsuta (Mitnan) with emphasis on hand papermaking. Econ Bot 37 (3): 310-321.

Sefidkon F, Abbas K, Jamzad Z and Ahmadi S. 2007. The effect of distillation methods and stage of plant growth on the essential oil content and composition of Satureja rechingeri Jamzad. Food Chem 100 (3): 1054-1058. DOI: 10.1016/j.foodchem.2005.11.016

Taran M, Ghasempour RH and Shirinpour E. 2010. Antimicrobial activity of essential oil of Ferulago angulata subsp. Carduchorum. Jundishapur J Microbiol 3 (1): 10-14.

Trigui M, Benhsouna A, Tonsi S, Jaoua S. 2013. Chemical composition and evaluation of antioxidant and antimicrobial activities of Tunisian Thymelaea hirsuta with special reference to its mode of action. Industr Crops Prod 41 (1): 150-157. DOI: 10.1016/j.indcrop.2012.04.011

Viljoen A M, Denirci B, Baser K H C, Potgieter C J and Edwards T J. 2006. Micro distillation and essential oil chemistry- a useful tool for detecting hybridisation in Plectranthus (Lamiaceae). South African J Bot 72 (1): 99-104. DOI: 10.1016/j.sajb.2005.05.003

Yahyaoui M, Bouajila J, Camy S, Condoret J-S, Abderabba M. 2014. Comparison of chemical composition and yield of Thymelaea hirsuta volatile oils obtained by supercritical carbon dioxide extraction and hydrodistillation methods. A Quarterly Open Access Scientific Journal ISEO. Abstracts Nat. Vol. Essent. Oils, Special Issue. Publisher: Badebio Ltd. Turkey (7-10 September) 1: 267.

Yahyaoui M, Bouajila J, Cazaux S, Abderrabba M. 2018b. The impact of regional locality on chemical composition, antioxidant and biological activities of Thymelaea hirsuta L. extracts. J Phytomed 41 (1): 13-23. DOI: 10.1016/j.phymed.2018.01.010.

Yahyaoui M, Ghazouani N, Saoudi S, Sifaoui I, Chammem N, Abderrabba M. 2018a. Experimental design methodology application in the optimization of phytochemical compounds extraction and 
antioxidant activity of Thymelaea hirsuta extracts. J Mater Environ Sci 9 (5): 1551-1561.

Yahyaoui M, Ghazouani N, Sifaoui I, Abderrabba M. 2017. Comparison of the effect of various extraction methods on the phytochemical composition and antioxidant activity of Thymelaea hirsuta L. aerial parts in Tunisia. Biosci Biotechnol Res Asia 14 (3): 997-1007. DOI: $10.13005 / \mathrm{bbra} / 2534$

Ziyyat A, Legssyer A, Mekhfi H, Dassouli A, Serhrouchni M, Benjelloun W. 1997. Phytotherapy of hypertension and diabetes in oriental Morocco. J Ethnopharmacol 58 (1): 45-54 